\title{
TIME MARCHES ON
}

\author{
By MARY G. DOBEYN, \\ (A story based on fact having happened in the very early days of Physiotherapy in South Africa.)
}

\begin{abstract}
All day long the Zulu voices accompanied Barrington as he moved about his work in the Physiotherapy Department attached to the native hospital. He grew accustomed to this musical background-the deep, rich voices of the gailyblanketed men and the higher notes of the women with piccanins on their backs, as the patients waited to be treated with the white man's machines. They were strange machines that clicked, or hissed, or hummed quietly-that warmed their bodies or brought back movement to injured limbs.

Barrington did not realise how deeply this sound had penetrated him until that morning when it stopped-stopped suddenly, as if the conductor of some orchestra had held up his hand and the instrumentalists were waiting and watching for the downbeat that would sweep them again into the rhythm of the music.
\end{abstract}

The silence fell while Barrington was working in one of the side-cubicles; so strange was the sensation that he drew aside the curtains and stepped into the middle of the room.

Facing him were the benches where the waiting patients sat. Usually the black faces were alight with amusement and expectation, in spite of the pains which their owners nursed, for once their terror of the white man's medicine had vanished, the treatment became a huge joke. But now the flash of teeth, the ready smiles, had gone; the eyes were watchful and cautious.

Standing before the crowded benches was the tall and fantastic figure -imposing in its final effect, but in detail merely ridiculous and grotesque. Fully six feet high, and well-proportioned, the figure was that of a buxom black woman. Her dress-barbarous even by the beads-andblankets standards of the other Africans-explained the sudden silence. She was Nonhla Kanipo, the witch-doctor, in full array.

Barrington made no move towards the woman, but thought: "Here's trouble." Anything that interfered with routine looked like trouble to Barrington. In the one meagerly-staffed hospital for a hundred miles, it was hard enough to treat the patients who came to him, without the luxury of diversions. He had given up a lucrative private practice among the white people of Johannesburg so that he could serve the natives, and he sometimes remembered that sacrifice. He did not regret it, but he had a feeling that as he had made it he should at least be left alone to get on with the job.

And he knew that the witch-doctors, both men and women, were jealous of the work his hospital was doing. It meant fewer patients for them, and falling prestige.

Slowly, conscious of the effect she had created, Nonhla Kanipho approached him. A kilted skirt of cow hide, scraped and beaten to the thinness of a fine tweed, swung from her broad hips. The lower parts of her legs were painted white, and anklets of metal and of monkey fur covered her ankles. Her heavy breasts bulged under a man's white singlet, which was her only concession to modernity. Bones, phials, beads and small skin pouches of herbs hung from her neck, and dangled in strings towards her waist.

Her face and head were ornamented in fearsome fashion. Daubs of paint outlined the cteek-bones and the lines flaring from the broad nostrils to the chin; each lock of frizzy hair was straightened by intertwisting with coloured beads and black thread, until it hung round her face and neck to her shoulders. Through this she peered, as if through a curtain of glass beads.
And as she walked the insignia of her office-the dried, airfilled bladder of a goat, attached to her hair-rose and bobbed in the air behind her.

Barrington studied what he could see of her impassive face as she moved pontifically towards him. Behind the beads, above the painted cheek bones, a pair of sharp black eyes regarded him intently. Barrington was suddenly aware that they held a twinkle of intelligence.

Then he saw what her powerful figure had hidden-a younger woman, herself tall but easily topped by the witchdoctor. Barrington recognised her as his patient, Maria Ndlovu. She had been carried to the hospital with a serious leg injury, and after an operation Barrington had given the thigh muscles electrical stimulation to strengthen the leg.

A gleam of amusement penetrated Barrington's habitual anxiety. He thought: So Maria is her patient, too. What do I do now-tell her to clear out, or hear a second opinion?

He said blandly, determined to score the first point off the witch-doctor: "Do you need some kind of treatment? I don't seem to have your name on by books."

The rustle along the benches told him that his thrust had gone home. Those who understood English repeated his remark softly in Zulu to the others. They waited tensely for the next round. Though they had taken the white man's medicine, superstition died hard and the witch-doctor's power still looked formidable. Barrington had the uneasy feeling that news of this encounter would travel like a veld-fire through the daub-and-wattle huts. If he was shown at a disadvantage, it would be more than a personal failure; the prestige of the hospital and the white man's medicine would take a knock. The natives, who had taken so long to be persuaded that the hospital would cure and not kill them, could easily retreat on a wave of emotion. The work of years might be ruined almost overnight.

A flicker of a smile crossed the broad features of Nonhla Kanipo. To Barrington's surprise she answered him in English.

"I need none of your treatment, white man. My medicines are more powerful than any you know. But I have come with my cousin, a silly girl who believes that you can do what I, Nonhla Kanipho, cannot."

Barrington waited calmly for her to continue.

"My cousin says that you have some medicine which can make her leg move when she does not want it to. I should like to see this great magic - if it is true."

She was talking about the Faradic current, thought Barrington.

"It's true all right," he said.

"I do not believe in such a machine," said the giantess, shaking her head. "The girl says that this machine does not slap her leg or twist it. How then can it make her leg move? It is lies." She turned to the waiting patients and said in Zulu: "I would like to see the white man's machine that could make $m y$ leg move if I did not want it to."

Now I have her on toast, thought Barrington triumphantly. I only need to give a demonstration on Nonhla Kanipho, and by tomorrow the news will be round the kraals within a ten-mile radius. The natives will all know how the mighty witch-doctor Nonhla Kanip'o could not keep her leg still against the white man's machine. It would do more good than five years' health propaganda among the chiefs. 
He said steadily: "I'll show you how my machine can make even your mighty leg move-if you are not afraid."

Nonhla Kanipho's eyes flashed angrily.

"Why should I fear your medicines, any more than I fear a dead snake on the path, or a little boy who roars like a lion?"

Barrington indicated an empty cubicle, and told his orderly to wheel in the apparatus. Haughtily the witchdoctor lowered her great form onto the couch. The waiting patients crowded round expectantly. They knew on their own limbs the machine could do what was claimed for itbut might not Nonhla Kanipho have magic strong enough to withstand its power?

A covetous gleam came into the eyes of the witch-doctor at the sight of the apparatus, with its shining white enamel and black switches, and the knobs with which the operator could choose the current he wanted.

Barrington attached the pads to her thigh, and plugged in to the main switch on the wall.

The rattle of beads as the witch-doctor turned her head to follow his every movement was accompanied by a sharp intake of breath; she was almost breathless with suppressed excitement, but her face was still impassive. Barrington could not remember seeing a Zulu with such self-possession.

The red pilot light on the machine glowed, and Barrington turned the selector switch to the faradic current. There was a click as the automatic surger came into operation, he increased the strength of the current.

As he turned the knob, the first movement began along the length of the witch-doctor's thigh. Down went the knee, and the great extensor muscle stood out strongly as the upward surge reached its peak. Then the knee relaxed and bent as the current weakened, only to work up again to a strong movement.

"Hau!" The witch-doctor's cry was a strange mixture of wonder and rage.

Barrington grinned as he watched her face. It expressed conflicting emotions of wonder, frustration and defeat. A black finger came out and touched, almost caressingly, the shiny surface of the machine. Barrington said nothing, and Nonhla Kanipho's hand hovered over each switch in turn without actually touching any. He was surprised to see that the woman followed each movement he had made, as if memorising them.

Suddenly she made an imperious gesture, and Barrington switched off the current.

"Strong medicine, eh?" he said.

She did not reply for a moment. Then she said with unwonted humility: "Strong medicine indeed." Barrington translated the words for the benefit of the onlookers. He felt that his victory was complete.

"How much would this machine cost to buy?" the witchdoctor asked softly, almost reverently.

"Hundreds of pounds."

Her face did not change.

"But this," she said, pointing to the main switch on the wall, "cannot be bought with the machine. How could such a thing work in the kraals?"

"It couldn't," said Barrington. "The power comes from these pylons"- and he pointed to the steel monsters bestriding the veld outside.

Her face fell. "But is there nothing like this that will work without the power?"

Barrington thought of the wasted minutes and the growing crowd of waiting natives. But for once he could afford to be indulgent. Today he had struck a blow for science.

Yes, he replied, there were battery-operated machines, cheaper than this one. They had one in the stockcupboarda small one in a suitcase which was used for emergencies, or in wards where the large machine could not be taken.

"And where can you buy such a machine?"

"This came from Durban . .." He broke off. "Thinking of going in for one? You'd have to sell half your cattle to pay for it."

He could not help grinning at the absurdity of his notion.

\section{This hygienic}

\section{Physiotherapist Uniform has so many good points!}

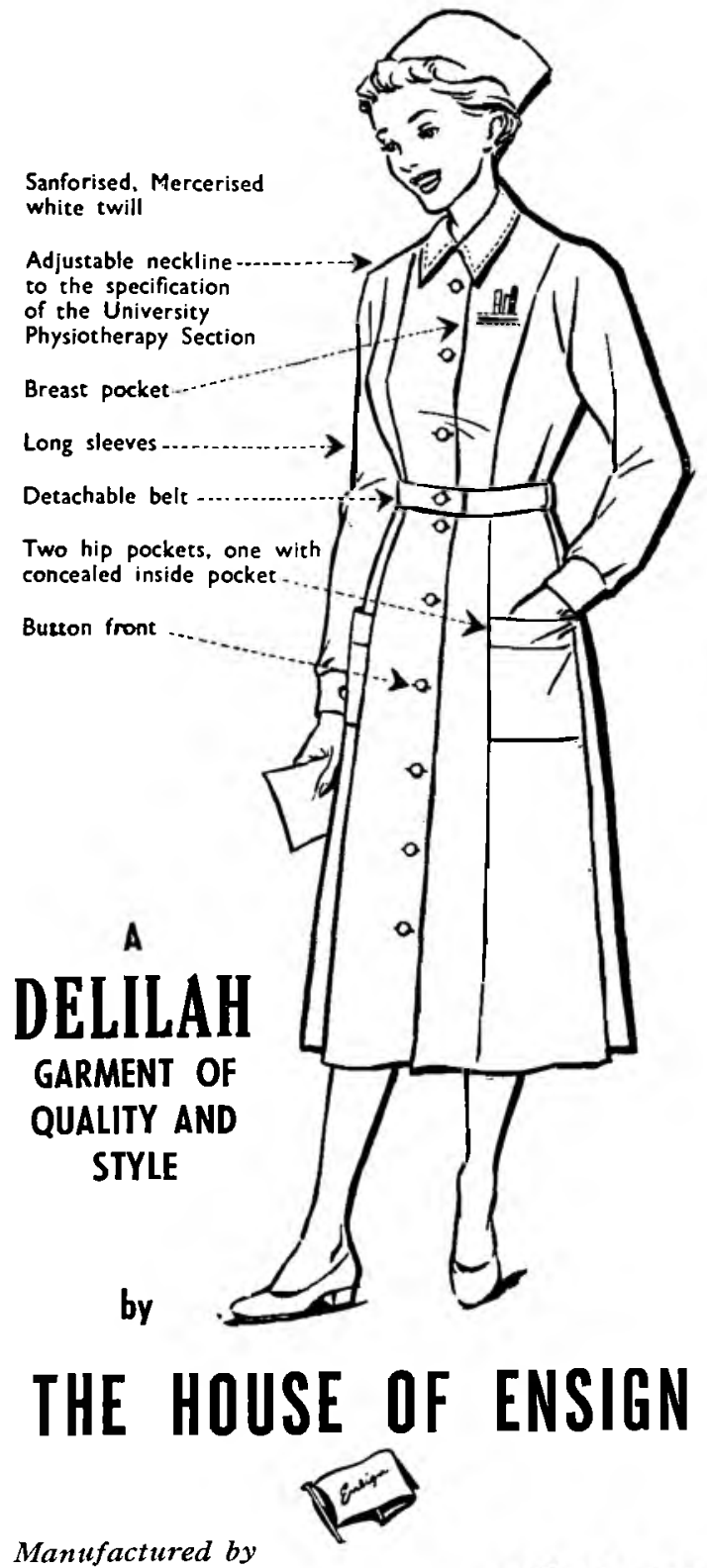

The AFRICAN CLOTHING FACTORY (Susign) Ltd.

P.O. BOX 1098 CAPE TOWN

and obtainable from good clothing stores everywhere 